\title{
Structures of Biological Minerals in Dental Research
}

\author{
Mathai Mathew and Shozo Takagi \\ American Dental Association \\ Health Foundation, \\ Paffenbarger Research Center, \\ National Institute of Standards and \\ Technology, \\ Gaithersburg, MD 20899-0001 \\ USA \\ mathai.mathew@nist.gov \\ shozo.takagi@nist.gov
}

Structural features of some calcium phosphates of biological interest are described. Structure of hydroxyapatite (OHAp), considered as the prototype for the inorganic component of bones and teeth is discussed with respect to the kinds and locations of ionic substitutions. Octacalcium phosphate (OCP), is a probable precursor in biological mineralization. OCP has a layer type structure, with one layer quite similar to that of OHAp and the other, a hydrated layer consisting of more widely spaced $\mathrm{Ca}$, and $\mathrm{PO}_{4}$ ions and the water molecules. The closeness of fit in the apatitic layers of OCP and OHAp accounts for the epitaxial, interlayered mixtures formed by these compounds and the in situ conversion of OCP to OHAp. Possible roles of OCP in biological mineralization are discussed.

Key words: biominerals; calcium phosphates; crystal structure; fluorapatite; glaserite; hydroxyapatite; octacalcium phosphate.

Accepted: August 22, 2001

Available online: http://www.nist.gov/jres

\section{Introduction}

The crystallography program at the American Dental Association Health Foundation, Paffenbarger Research Center, was initiated in the early 1970s. The program was designed to investigate the crystal structures of biological minerals and related compounds associated with or with potential bearing in mineralization processes. Since calcium phosphates comprise the largest group of biominerals in vertebrate animals, most of the work carried out, was centered on or around calcium phosphates or related materials. Crystal structures of a number of pyrophosphates, carbonates, bisphosphonates, and highly hydrated phosphates and arsenates of calcium, magnesium and strontium were also investigated. This review will summarize the structural features of calcium phosphates relevant to biomineralization. The phosphates containing $\mathrm{HPO}_{4}{ }^{2-}$ and $\mathrm{PO}_{4}{ }^{3-}$ generally constitute the biologically relevant calcium phosphates. Phosphates with only $\mathrm{H}_{2} \mathrm{PO}_{4}{ }^{-}$ions are not normally found under physiological conditions, but are commercially important as components in fertilizers.

\section{Discussion-Calcium Phosphates}

The known pure calcium phosphates have been classified into three major structural types [1]: (i) the apatite type, $\mathrm{Ca}_{10}\left(\mathrm{PO}_{4}\right)_{6} \mathrm{X}_{2}$, which includes the derivatives of hydroxyapatite $\left(\mathrm{X}=\mathrm{OH}^{-}\right)$and fluorapatite $\left(\mathrm{X}=\mathrm{F}^{-}\right)$as well as those related to apatite-type structures such as octacalcium phosphate (OCP), [Octacalcium bis(hydrogenphosphate) tetrakis(phosphate) pentahydrate], $\mathrm{Ca}_{8}\left(\mathrm{HPO}_{4}\right)_{2}\left(\mathrm{PO}_{4}\right)_{4} \cdot 5 \mathrm{H}_{2} \mathrm{O}$ and tetracalcium phosphate (TTCP), $\mathrm{Ca}_{4}\left(\mathrm{PO}_{4}\right)_{2} \mathrm{O}$; (ii) the glaserite type, which can be considered to include all polymorphs of tricalcium phosphates (TCP), $\mathrm{Ca}_{3}\left(\mathrm{PO}_{4}\right)_{2}$; and (iii) the $\mathrm{Ca}-\mathrm{PO}_{4}$ sheet-containing compounds, which include dicalcium 
phosphate dihydrate (DCPD), $\mathrm{CaHPO}_{4} \cdot 2 \mathrm{H}_{2} \mathrm{O}$, dicalcium phosphate anhydrous (DCPA), $\mathrm{CaHPO}_{4}$, and monocalcium phosphates, $\mathrm{Ca}\left(\mathrm{H}_{2} \mathrm{PO}_{4}\right)_{2} \cdot \mathrm{H}_{2} \mathrm{O}$ and $\mathrm{Ca}\left(\mathrm{H}_{2} \mathrm{PO}_{4}\right)_{2}$. A number of highly hydrated phosphatic compounds have been included as a new type of calcium phosphate [1], struvite-type structures, after the biomineral struvite, $\mathrm{Mg}\left(\mathrm{NH}_{4}\right) \mathrm{PO}_{4} \cdot 6 \mathrm{H}_{2} \mathrm{O}$, although these compounds do not represent pure calcium phosphates. Amorphous calcium phosphate (ACP), a possible precursor to bioapatite, may be related to one or more of the structural types discussed above.

\subsection{Apatite Type Structures}

Apatites are a structural type for compounds of the general formula $\mathrm{M}_{10}\left(\mathrm{XO}_{4}\right)_{6} \mathrm{Y}_{2}$ rather than specific compounds. In general, they are known to be capable of accommodating a wide variety of modifications and combinations of substitutions of ions and groups within the apatitic lattice. However, the term "apatite" has been extensively and synonymously used to represent the calcium phosphates, $\mathrm{Ca}_{10}\left(\mathrm{PO}_{4}\right)_{6} \mathrm{X}_{2}$, where $\mathrm{X}=\mathrm{F}^{-}, \mathrm{OH}^{-}$, or $\mathrm{Cl}^{-}$and this concept will be followed in this review. Apatites are thermodynamically the most stable phases among the calcium phosphates and, therefore, can be considered as the probable end product in many reactions.

\subsubsection{Hydroxyapatite}

Hydroxyapatite (OHAp), $\mathrm{Ca}_{10}\left(\mathrm{PO}_{4}\right)_{6}(\mathrm{OH})_{2}$, is used as a model for inorganic component of bones and teeth. However, apatites as they occur in biological tissues, mineral formations and laboratory products can incorporate a wide variety of impurities and are seldom found in pure stoichiometric form.

The most common form is hexagonal and the crystal structure has been described in the space group $\mathrm{PG}_{3} / \mathrm{m}$ (No. 176) with lattice parameters $a=b=9.432 \AA$ and $c=6.881 \AA, Z=1$ [2]. The structure is depicted in Fig. 1. The $10 \mathrm{Ca}^{2+}$ ions occupy two crystallographically different symmetry sites, $4 f$ and $6 h$. Four $\mathrm{Ca}^{2+}$ ions $(4 f)$ are located in columns along the three-fold axes at $1 / 3$, 2/3, 0 and 2/3,1/3, 0 separated by approximately onehalf of the $c$-axis. These are commonly referred to as $\mathrm{Ca} 1$ (or column $\mathrm{Ca}$ ). $\mathrm{Ca} 1$ is coordinated to nine $\mathrm{O}$ atoms, with six shorter bonds that define an approximate trigonal prism and three longer bonds capping the prism faces. The $\mathrm{Ca}-\mathrm{O}_{9}$ polyhedra share the trigonal faces to form chains parallel to the $c$-axis. The remaining six $\mathrm{Ca}^{2+}$ ions ( $6 h$ sites, referred to as $\mathrm{Ca} 2$ or triangu$\operatorname{lar} \mathrm{Ca}$ ) form two triangular sets at $z=1 / 4$ and $3 / 4$ on the mirror planes. The $\mathrm{Ca} 2$ ions are seven-coordinated, with six $\mathrm{O}$ atoms and one $\mathrm{OH}^{-}$ion. The six $\mathrm{PO}_{4}{ }^{3-}$ ions

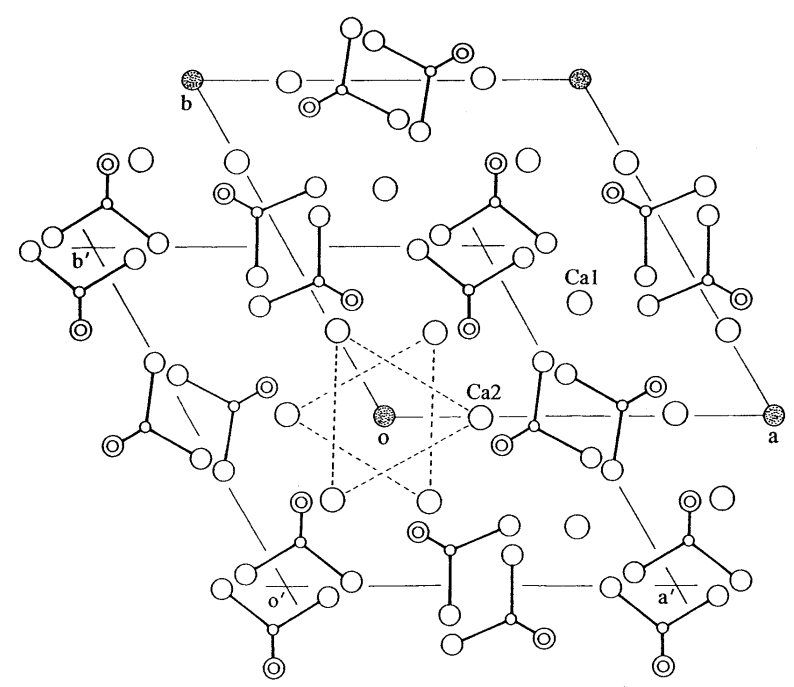

Fig. 1. Crystal structure of FAp or hexagonal OHAp projected down the $c$-axis. The corners of the unit cell (marked by shaded circles) are occupied by $\mathrm{F}^{-}$in FAp and by $\mathrm{OH}^{-}$in OHAp. An alternate choice of unit cell is identified as $a^{\prime}$ and $b^{\prime}$.

occupy $6 h$ positions similar to the $\mathrm{Ca} 2$ ions, in expanded triangular positions. Adjacent $\mathrm{Ca} 1$ and $\mathrm{Ca} 2$ polyhedra are linked through oxygen atoms of the $\mathrm{PO}_{4}{ }^{3-}$ tetrahedra. Because of the crystallographic mirror symmetry imposed by the space group, each $\mathrm{OH}^{-}$ion has to be considered at statistically disordered positions $(4 e)$ both above and below the mirror planes at $z=1 / 4$ and 3/4. It has been shown by neutron diffraction studies [2] that the oxygen atoms in hydroxide ions are $0.34 \AA$ away from the mirror plane with the $\mathrm{OH}^{-}$direction pointing away from the mirror planes. An averaged structure could imply that in approximately half the unit cells the $\mathrm{OH}^{-}$ions are pointed upward from the mirror plane and in the remaining unit cells they are pointed downward. However, this statistical disordering need not be completely random. At least some short range ordering is to be invoked such as $\mathrm{OH}-\mathrm{OH}-\mathrm{OH}$...HO-HO. The reversal of the $\mathrm{OH}^{-}$direction can be achieved by replacement of an $\mathrm{OH}^{-}$by $\mathrm{F}^{-}$or $\mathrm{Cl}^{-}$etc. or by a vacancy. Thus, the hexagonal OHAp is probably never strictly stoichiometric.

Stoichiometric OHAp has been described as monoclinic, space group $P 2_{1} / b$ having cell parameters $a=9.4214(8) \AA, b=2 a, c=6.8814(7) \AA, \gamma=120^{\circ}$, with twice as many formula units per unit cell as in the hexagonal unit [3]. The structure is closely related to that of the hexagonal form, but with no restrictions imposed by the mirror symmetry. The $\mathrm{Ca}^{2+}$ and $\mathrm{PO}_{4}{ }^{3-}$ ions occupy similar positions as in the hexagonal form. However, the $\mathrm{OH}^{-}$ions are located in two different columns. Within each column all the $\mathrm{OH}^{-}$ions have the same direction of displacements from $z=1 / 4$ as in the 
hexagonal form. All the $\mathrm{OH}^{-}$ions in one column point upward, while those in the other column point downward. Thus, there is no disordering of the $\mathrm{OH}^{-}$ions in the monoclinic form. The monoclinic form is formed only under favorable thermal conditions.

\subsubsection{Fluorapatite}

Fluorapatite (FAp), $\mathrm{Ca}_{10}\left(\mathrm{PO}_{4}\right)_{6} \mathrm{~F}_{2}$, is the most stable among the apatites. FAp is hexagonal with the space group $P 6_{3} / m$ and lattice parameters, $a=b=9.367(1) \AA$ and $c=6.884(1) \AA, Z=1$ [4]. The positions of the two sets of $\mathrm{Ca}^{2+}$ ions and the $\mathrm{PO}_{4}{ }^{3-}$ ions are nearly identical to those of OHAp. However, the $\mathrm{F}^{-}$ions occupy the center of the $\mathrm{Ca} 2$ triangles ( $6 h$ positions), on the mirror planes at $z=1 / 4$ and $3 / 4$.

\subsubsection{Chlorapatite}

Chlorapatite (ClAp), $\mathrm{Ca}_{10}\left(\mathrm{PO}_{4}\right)_{6}(\mathrm{Cl})_{2}$, has been described in the hexagonal space group $P 6_{3} / \mathrm{m}$, with cell parameters, $a=b=9.598(2) \AA, c=6.776(4) \AA, Z=1$ [5]. Like $\mathrm{OH}^{-}$in OHAp, the $\mathrm{Cl}^{-}$is also disordered, displaced from the midpoint of the $\mathrm{Ca} 2$ triangles, and in positions $1.2 \AA$ above and below the mirror planes. The $\mathrm{Cl}^{-}$is so far removed from the mirror plane towards the midway point between the two $\mathrm{Ca} 2$ triangles, that an additional weak bond develops between the $\mathrm{Ca} 2$ and a second $\mathrm{Cl}^{-}$ion.

Stoichiometric ClAp has also been found to crystallize in the monoclinic space group with space group $P 2_{1} / b$ having cell parameters $a=9.628(5) \AA, b=2 a$, $c=6.764(5) \AA, \gamma=120^{\circ}, Z=2$ [6]. The structure is very similar to the hexagonal one, but the $\mathrm{Cl}^{-}$ions are ordered in two columns on pseudohexagonal axes as in the case of the monoclinic OHAp.

\subsubsection{Substituted Apatites}

OHAp can incorporate a wide variety of substitutions for $\mathrm{Ca}^{2+}, \mathrm{PO}_{4}{ }^{3-}$, and/or $\mathrm{OH}^{-}$ions. Substitution of other elements for $\mathrm{Ca}^{2+}$ and $\mathrm{PO}_{4}{ }^{3-}$ is relatively minor in most natural mineral samples. Natural minerals of the composition, $\mathrm{Ca}_{10}\left(\mathrm{PO}_{4}\right)_{6}(\mathrm{~F}, \mathrm{OH}, \mathrm{Cl})_{2}$ exhibit large variations in $\mathrm{F}^{-}, \mathrm{OH}^{-}$, and $\mathrm{Cl}^{-}$contents. Pure end-members are uncommon in nature, but binary and ternary compositions are widely reported.

Biological apatites are rarely stoichiometric, are usually calcium-deficient, and contain a wide variety of relatively small amounts of other substituent atoms or groups. A large number of proposals have been made to account for the nonstoichiometry of bioapatites. The major cause of nonstoichiometry is the incorporation of impurities, usually substitutionally for $\mathrm{Ca}$, but also inter- stitially. Both $\mathrm{HPO}_{4}{ }^{2-}$, and structurally incorporated water occur in some synthetic and biological apatites, but their structural locations are not known.

\subsubsection{1 $\mathrm{X}^{-}$Ion Substitution}

The $\mathrm{X}^{-}$ion positions in apatites or the " $\mathrm{X}$ ion channels", as they are often referred to, appear to be the sites of a great deal of interesting activity in apatites. The $\mathrm{X}^{-}$ ion positions in apatites are substituted by a variety of ions, frequently by $\mathrm{OH}^{-}, \mathrm{F}^{-}$, and $\mathrm{Cl}^{-}$, but also by $\mathrm{CO}_{3}{ }^{2-}$ and $\mathrm{O}^{2-}$, or by vacancies or any combination of these. In pure form each $\mathrm{X}^{-}$ion takes up its own particular location, as noted above. However, when two or more of these ions are present at the same time, they interact with each other to produce effects not predicted from the knowledge of the structures of the end-member alone $[5,7,8]$. The positional $z$-parameters of the $\mathrm{X}^{-}$ ions are shifted from their normal positions in the pure form, but the effects are more pronounced when the larger $\mathrm{Cl}^{-}$ions are involved. A monoclinic form of a natural ternary apatite, $\mathrm{Ca}_{5}\left(\mathrm{PO}_{4}\right)_{3}\left(\mathrm{~F}_{0.29}, \mathrm{Cl}_{0.47}, \mathrm{OH}_{0.24}\right)$, space group $P 2_{1} / b$, has been reported [8]. There are two anion columns in the unit cell and both columns contain all three anions. The reduction in symmetry from hexagonal to monoclinic results from ordering of the column anions in each column in one of the two symmetryequivalent anion sites present in the hexagonal ternary apatite.

\subsubsection{Carbonate Apatites}

Carbonate apatites are of special interest in biological systems as the inorganic component of bone and teeth. There are two generally accepted locations for the $\mathrm{CO}_{3}{ }^{2-}$ ion in the apatite lattice: one on the hexad axis at the $\mathrm{OH}^{-}$ion site (type-A) and the other for $\mathrm{PO}_{4}{ }^{3-}$ (typeB). Type-B substitution would require involvement of additional ions for charge balance. Biological apatites are principally type-B carbonates, but with small amount of type-A [9]. However, neither of these cases has been confirmed by complete structure analysis and the structure of carbonate-apatite remains controversial.

\subsubsection{Cation Substitution}

The incorporation of foreign cations in the apatite lattice is expected to change the bulk properties of the apatite. The structures of a number of synthetic substituted apatites were investigated to evaluate the structural changes associated with the substitution. Lead is known as a "bone seeker" in that it accumulates in bone and tooth mineral. In a lead apatite study, a short $\mathrm{Pb}-\mathrm{O}$ distance observed indicating a covalent bond may ac- 
count for this lead incorporation [10]. The structure of calcium-lanthanam apatite shows that cation ordering in apatites are strongly dependent on the properties of the constituent ions [11]. However, in a series of Ba-rare earth-Na apatites [12] the results indicate the substitutions to be unexpectedly complex to derive any general prediction.

\subsection{Octacalcium Phosphate}

The crystal structure of octacalcium phosphate (OCP), $\mathrm{Ca}_{8}\left(\mathrm{HPO}_{4}\right)_{2}\left(\mathrm{PO}_{4}\right)_{4} \cdot 5 \mathrm{H}_{2} \mathrm{O}$, was initially determined in 1962 [13] and refined later [14]. The crystals are triclinic, space group $P \overline{1}$, with cell parameters $a=19.692(4) \AA, \quad b=9.523(2) \AA, \quad c=6.835(2) \AA$, $\alpha=90.15(2)^{\circ}, \beta=92.54(2)^{\circ}, \gamma=108.65(1)^{\circ}$ and $Z=2$. The structure of OCP is illustrated in Fig. 2. The positions of all atoms in the region $x=0$ to $\approx 1 / 4$ in OCP corresponds very closely to that of the OHAp. This portion consists of two $\mathrm{Ca}^{2+}$ and two $\mathrm{PO}_{4}{ }^{3-}$ groups, corresponding to each triangular set and two Ca positions in one column in apatite, thus accounting for the $\mathrm{Ca}_{6}\left(\mathrm{PO}_{4}\right)_{4}$ unit. The center of inversion at $0,1 / 2,0$ extends this region to $x \approx-1 / 4$ and this region of $\mathrm{OCP}$, between $x \approx 1 / 4$ and $x \approx-1 / 4$ has been referred to as the "apatitic layer". Between $x \approx 1 / 4$ to $\approx 3 / 4$, the composition and the atomic positions of OCP are quite different from those of OHAp. This portion of the structure,

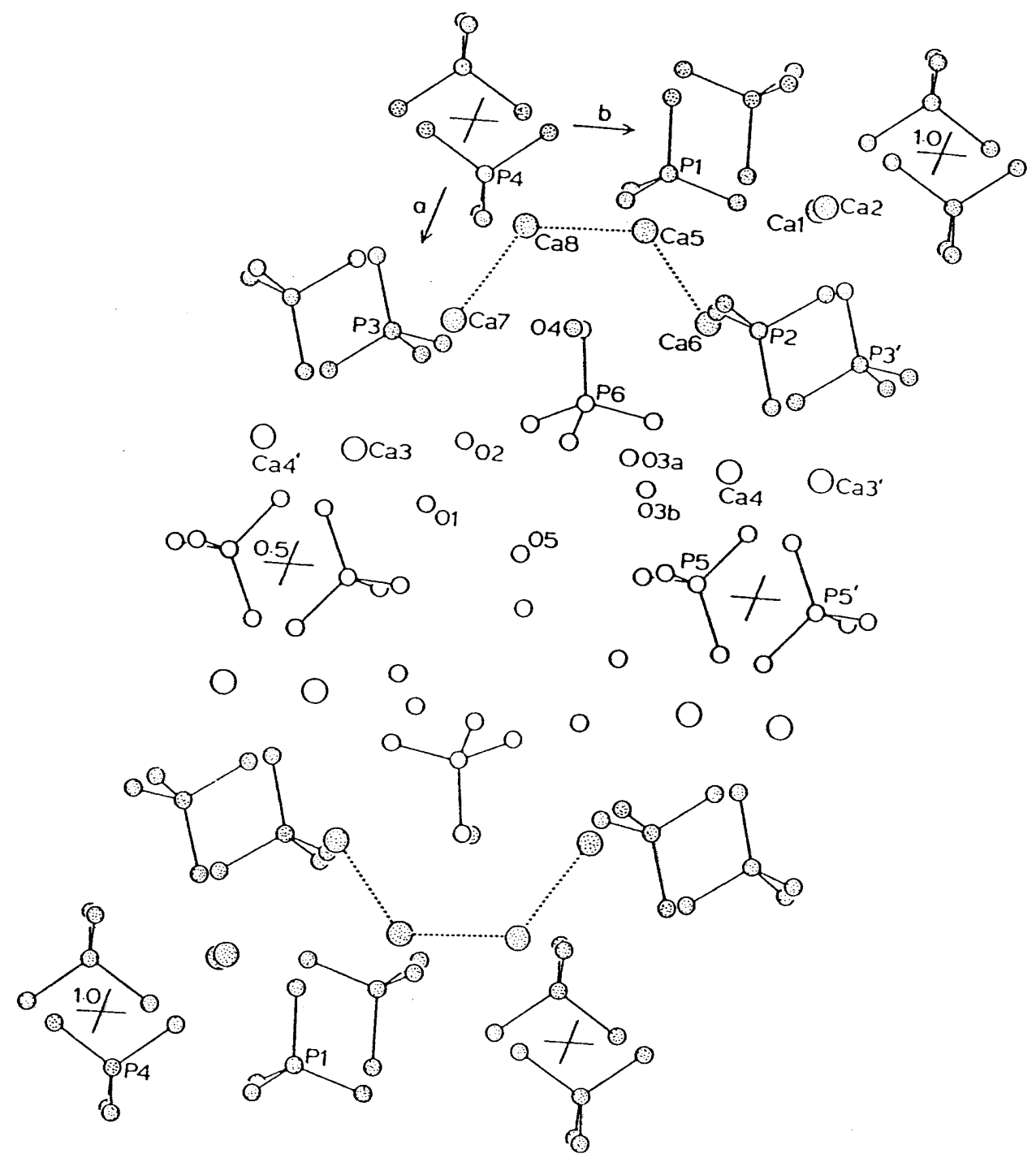

Fig. 2. Crystal structure of octacalcium phosphate projected down the $c$-axis. The region with shaded atoms is very similar to that of OHAp and has been referred to as the "apatitic" layer. Hydrogen atoms are omitted for clarity. 
containing the ten water molecules in the unit cell, is referred to as the "hydrated layer". The structure of OCP has been described in terms of alternating apatitic and hydrated layers parallel to the (100) face. Closer examination of the structure reveals that the "hydrated layer" is only a hydrated region or channel along the $c$-axis at the center of the unit cell at $1 / 2,1 / 2,0$, since the apatitic layers are held together by strong bonds involving the $\mathrm{Ca} 3, \mathrm{Ca} 4$, and the $\mathrm{HPO}_{4}{ }^{2-}$ (P5) groups along the $a$-axis.

The water molecules, O5, located near the center of the hydrated region, are not coordinated to any $\mathrm{Ca}^{2+}$ ion. The large thermal parameters of $\mathrm{O} 5$ might indicate partial occupancy at this site or disorder at several positions along this channel. The uncertainty in the numbers of water molecules in OCP may be due to the loosely bound $\mathrm{O} 5$ water being able to enter or leave the OCP lattice, depending on the external conditions. Regardless of the amount of $\mathrm{O} 5$ water, this region provides an open channel along the c-axis for the transport of $\mathrm{Ca}^{2+}$ or other ions that can be incorporated into the resulting apatitic products during the transformation or hydrolysis of OCP.
The overall structural relationship of the OCP and OHAp is shown in Fig. 3, where the atomic positions of OCP are superimposed on the structure of OHAp. Some similarity can be observed even in the hydrated layer. The positions of the two $\mathrm{Ca}^{2+}$ ions in the hydrated layer are also close to those of the column $\mathrm{Ca}^{2+}$ ions in apatite. Another notable feature is the location of the water molecule $(\mathrm{O} 4)$ and one oxygen atom of the $\mathrm{HPO}_{4}{ }^{2-}$ at the junction of the apatitic and hydrated layers $(x \approx 1 / 4)$. They correspond to pivotal positions of the $\mathrm{OH}^{-}$ions at the corners of the OHAp unit cell (at $z \approx 1 / 4$ and $\approx 3 / 4$ ). The importance of this feature and the closeness of the fit in the structures of OCP and OHAp can be seen if the complete "apatitic layer" of OCP is compared with a unit cell of OHAp, as shown in Fig. 4. If O4 occupies a pair of corners, $\mathrm{A}$ and $\mathrm{B}$ at $z=1 / 4$, the oxygen of the $\mathrm{HPO}_{4}{ }^{2-}$ will be at $z=3 / 4$ at these corners. The positions will be reverse for the corners at $\mathrm{C}$ and $\mathrm{D}$. For crystals to grow as OHAp, all these corner positions (ABCD at both $z=1 / 4$ and 3/4) must be occupied by $\mathrm{OH}^{-}$ions instead of water and $\mathrm{HPO}_{4}{ }^{2-}$. While the water molecule can be easily visualized at these sites in OHAp there is<smiles>O=C(O)OC(=O)C(=O)O</smiles>
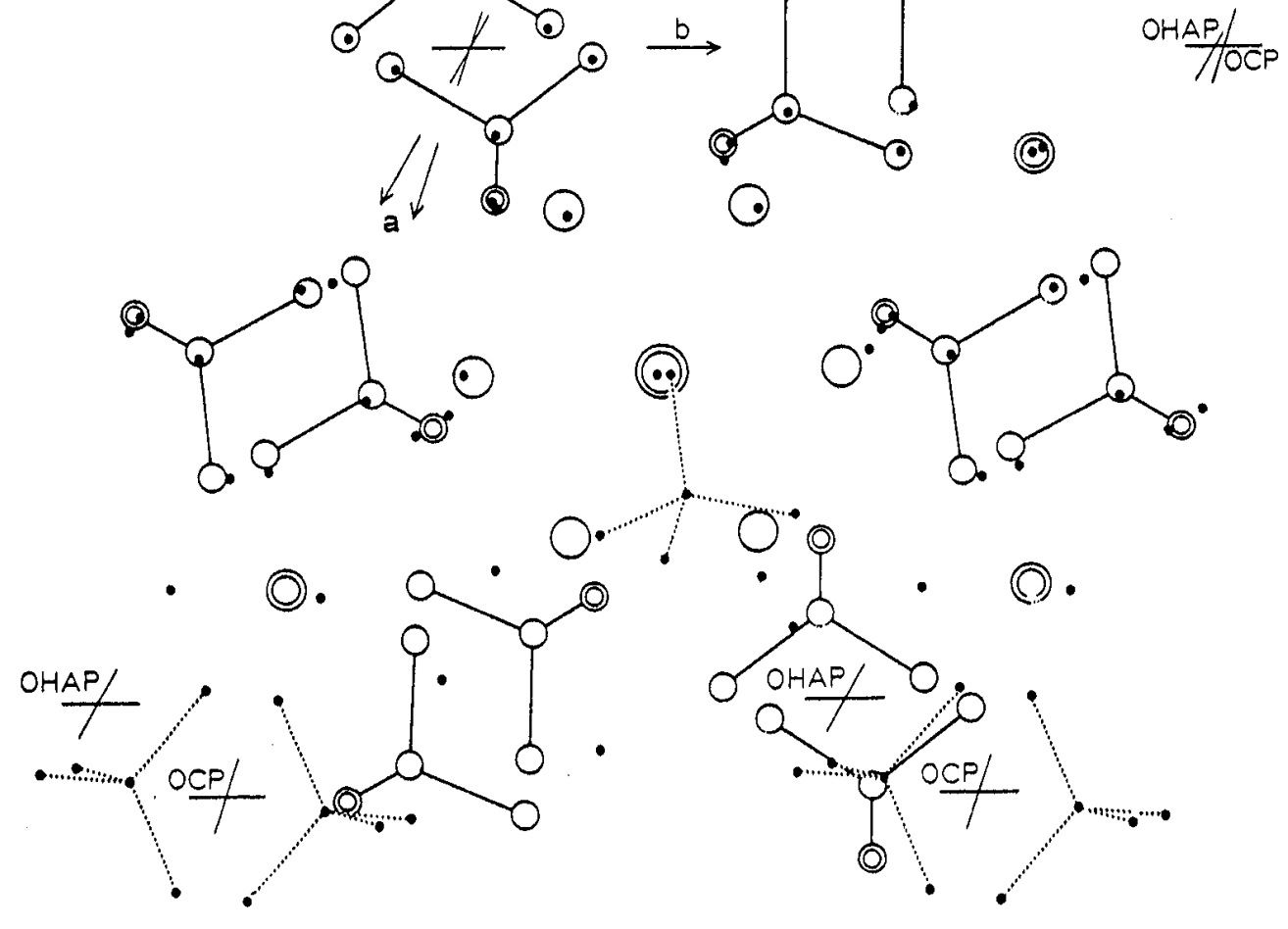

Fig. 3. The superposition of one OHAp cell (the alternate choice indicated in Fig. 1) with half of an OCP cell projected down its $c$-axis. The open circles represent atomic positions in OHAp, while the small filled circles represent those in OCP. 


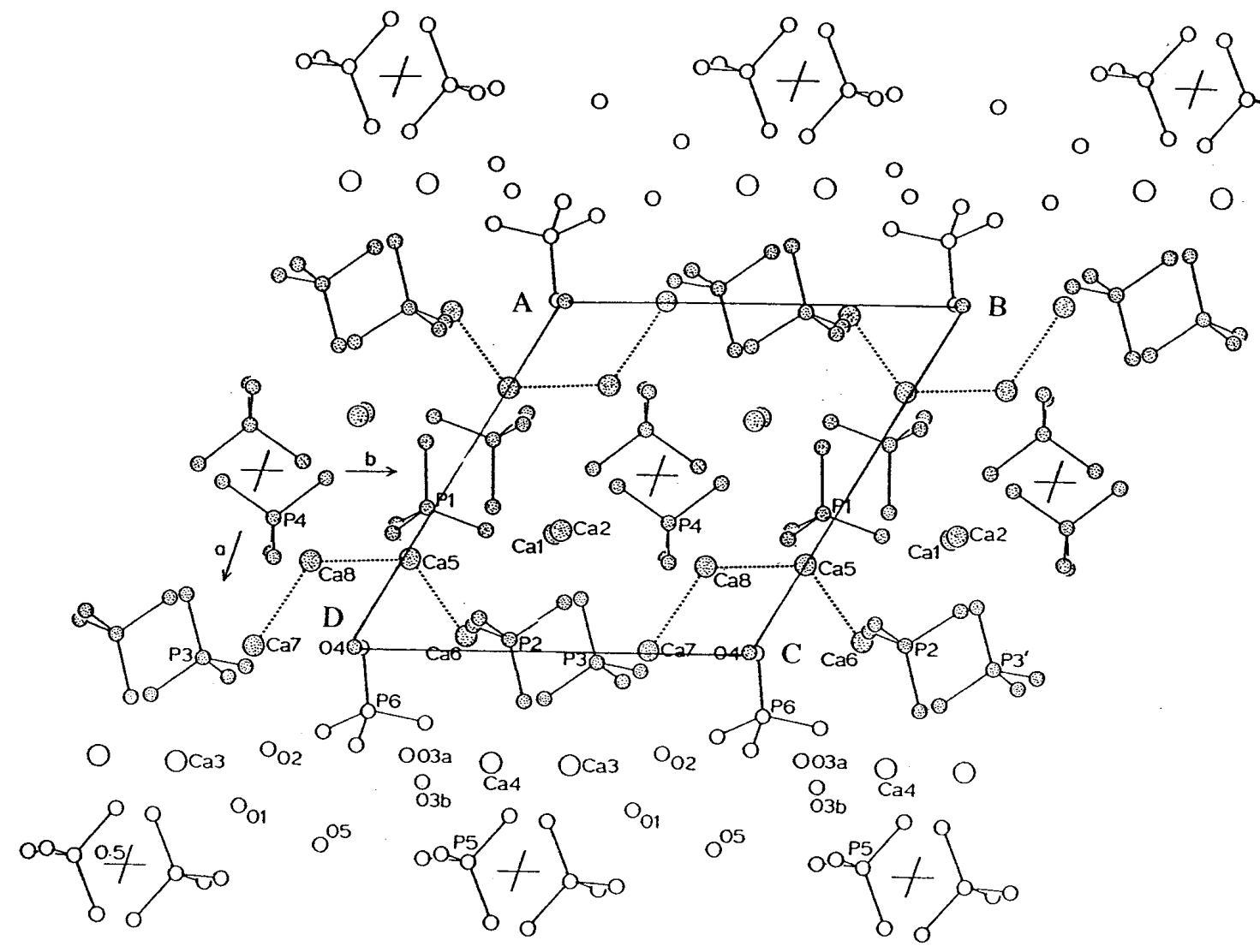

Fig. 4. Another view of the unit cell of OCP showing the apatitic layer as the central region. A unit cell corresponding to that of hexagonal OHAp is shown. The hydrated layers on the top and bottom represent the transition state.

no room for the $\mathrm{HPO}_{4}{ }^{2-}$. The pseudo-apatitic unit (ABCD, Fig. 4) containing the water molecules incorporated into true OHAp crystals offers a plausible route accounting for the lattice water molecules found in apatite. Bond valence calculations have indicated that the water molecule, $\mathrm{O} 4$ in $\mathrm{OCP}$, is likely to be at least partially substituted by an $\mathrm{OH}^{-}$ion [14]. This view is also supported by NMR studies showing the presence of $\mathrm{OH}^{-}$ions in the apatitic layer of OCP [15]. Existence of polymorphs of OCP attributed to the possible differences in bonding between the $\mathrm{HPO}_{4}{ }^{2-}$ ions and water molecules [16] may also be related to the possible disorder/substitution of $\mathrm{O} 4$ and/or O5 water molecules.

The closeness of the fit in the structures of OCP and OHAp has been used to account for the epitaxial growth and the formation of interlayered or lamellar mixtures by these two compounds [17]. Investigations of the structural models have predicted epitaxial growth of one compound on the other [18]. X-ray diffraction study of a calcium phosphate crystal that had optical properties intermediate between those of OCP and OHAp was found to diffract as independent crystals of OCP and OHAp with their $b$ - and $c$-axes collinear [17]. However, when OCP and OHAp layers are very thin and random, they are characterized as interlayered mixtures of OCP and OHAp. The diffraction peaks interact with one another so that the positions of the $(h 00)$ peaks shift with the $\mathrm{Ca} / \mathrm{P}$ molar ratio of the interlayered crystals [19]. The basic structure of the lamellar mixed crystals consists of apatitic lamellas sandwiching an OCP lamella [20].

The existence of interlayered mixtures of OCP and OHAp has been used to provide insights into the biomineralization processes, such as properties and nonstoichiometry of biological apatites, and a possible structural model for amorphous calcium phosphate $[21,22]$. The transition layer of OHAp to the aqueous phase has been considered to be equivalent to approximately half a unit cell of OCP on the surface of the $\{100\}$ faces of OHAp. However, the possible presence of a complete pseudo-apatitic unit, ABCD (Fig. 4) in OCP itself offers another interesting possibility. While the $\{100\}$ faces $\mathrm{AB}$ and $\mathrm{CD}$ would appear to present a different hydration of the OHAp surface, they are still possible candidates for epitaxial growth of OCP, as described above. From the structural point of view, the 
faces $\mathrm{BC}$ and $\mathrm{AD}$ are identical to the faces $\mathrm{AB}$ and $\mathrm{CD}$ and therefore, are also possible candidates for epitaxial growth of OCP. If all the faces of the pseudo-apatitic unit ABCD are hydrated, this completely hydrated unit may be used as a possible model for ACP and/or for hydrated tricalcium phosphates, which also exhibit an apatitic x-ray diffraction pattern.

\subsection{Tetracalcium Phosphate}

Tetracalcium phosphate (TTCP), $\mathrm{Ca}_{4}\left(\mathrm{PO}_{4}\right)_{2} \mathrm{O}$, is monoclinic, space group $P 2_{1}$, with unit cell parameters $a=7.023(1) \AA, b=11.986(4) \AA, c=9.473(2) \AA$ and $\beta=90.90(1)^{\circ}$ [23]. The $\mathrm{Ca}^{2+}$ and $\mathrm{PO}_{4}{ }^{3-}$ ions in TTCP are located in four sheets perpendicular to the $b$-axis. Each sheet contains two $\mathrm{Ca}-\mathrm{PO}_{4}$ columns and one $\mathrm{Ca}-$ $\mathrm{Ca}$ column. The arrangement of these columns is similar to those in glaserite where the oxide ions are extra. However, two adjacent sheets in TTCP form a layer that is closely related to that of apatite. TTCP is easily hydrolyzed in presence of DCPD or DCPA and water to form OHAp as the major ingredient of self-setting calcium phosphate cement developed in our laboratories [24] and used for repairing bone defects and cranial defects.

\subsection{Tricalcium Phosphates}

There are four polymorphs of anhydrous TCP: $\alpha$ $\mathrm{Ca}_{3}\left(\mathrm{PO}_{4}\right)_{2}(\alpha$-TCP $)$, the stable phase between $1120^{\circ} \mathrm{C}$ and $1470{ }^{\circ} \mathrm{C}$, but metastable below $1120^{\circ} \mathrm{C} ; \alpha^{\prime}$-TCP, stable above $1470{ }^{\circ} \mathrm{C} ; \beta-\mathrm{Ca}_{3}\left(\mathrm{PO}_{4}\right)_{2}(\beta$-TCP) stable below $1120^{\circ} \mathrm{C}$ and $\beta^{\prime}$-TCP stable at high pressures [2527]. None of these compounds is known to form in biological systems. However, their relevance to biomineralization is clear considering the facts that $\alpha$-TCP is easily hydrolyzed to OCP and that the mineral whitlockite, which is found in many biological mineralizations, has a structure very similar to that of $\beta$-TCP [28]. Although there are references in the literature [29] to hydrated tricalcium phosphates, they have not been clearly identified as discrete crystalline compounds.

\subsubsection{Glaserite-Type Structures}

Structures of $\alpha$ - and $\beta$-TCP have been classified as glaserite-type, named after the mineral glaserite, $\mathrm{K}_{3} \mathrm{Na}\left(\mathrm{SO}_{4}\right)_{2}$ [30]. In glaserite, the cations and anions are arranged in two types of columns in a hexagonal arrangement, one containing only cations, $\mathrm{Na}^{+}$and $\mathrm{K}^{+}$ (type I) and the other both cations and anions, $\mathrm{K}^{+}$and $\mathrm{SO}_{4}{ }^{2-}$ (type II). Since the ions in each column are tightly bound along this direction, the structure has been considered as hexagonal packing of rods [31]. There are twice as many type II columns as type I. Each type I rod is surrounded by six type II rods, and each type II rod by alternate type I and type II rods. Glaserite has a cation-anion ratio of $2: 1$. Although many of the glaserite related structures do not satisfy this condition, the discrepancy can be accounted for by imputed ionic vacancies along selected columns.

$\mathrm{CaK}_{3} \mathrm{H}\left(\mathrm{PO}_{4}\right)_{2}$ can be considered to have the closest similarity to the glaserite structure. Since the radius ratio of the cations in $\mathrm{CaK}_{3} \mathrm{H}\left(\mathrm{PO}_{4}\right)_{2}$ is nearly identical to that of glaserite and the 2:1 ratio of cations and anions is maintained, the presence of the proton on the $\mathrm{PO}_{4}{ }^{3-}$ group causes only very minor structural changes [32]. $\alpha$-TCP crystallizes in the monoclinic space group $P 2_{1} / a$ with $a=12.887(2) \AA, \quad b=27.280(4) \AA$, $c=15.219(2) \AA, \beta=126.20(1)^{\circ}, Z=24$ [33]. The $\mathrm{Ca}^{2+}$ and $\mathrm{PO}_{4}{ }^{3-}$ ions are packed in two kinds of columns along the $c$-axis, one containing only $\mathrm{Ca}^{2+}$ and the other both $\mathrm{Ca}^{2+}$ and $\mathrm{PO}_{4}{ }^{3-}$ ions in the ratio 1:2 (Fig. 5). All columns are distorted from linearity. The arrangement of these columns in a pseudohexagonal form is similar to that of glaserite. However, since $\alpha$-TCP does not have a 2:1 cation-anion ratio, its emulation of the glaserite structure requires cation vacancies with the formula $\mathrm{Ca}_{3} \square\left(\mathrm{PO}_{4}\right)_{2}$ where $\square=$ vacancy. All the cation vacancies are in the cation anion columns only, with the sequence ${ }^{\cdots} \mathrm{P}-\square-\mathrm{P}-\mathrm{Ca} \cdots$. The detailed environments of the $\mathrm{Ca}^{2+}$ ions in $\alpha$-TCP are quite different from those of the cations in glaserite, as expected from the different sizes of the ions in the two structures and the vacancies.

$\beta$-TCP crystallizes in the rhombohedral space group $R 3 c$ with unit cell parameters $a=10.439(1) \AA$, $c=37.375(6) \AA, Z=21$ (hexagonal setting) [34]. The structure of $\beta$-TCP has been described as a distorted version of the $\mathrm{Ba}_{3}\left(\mathrm{PO}_{4}\right)_{2}$ structure which has identical columns of $\mathrm{PO}_{4}-\mathrm{Ba}-\mathrm{Ba}-\mathrm{Ba}-\mathrm{PO}_{4}$ in a hexagonal arrangement. However, since the $\mathrm{Ca}^{2+}$ ion is too small to provide ideal $\mathrm{Ba}_{3}\left(\mathrm{PO}_{4}\right)_{2}$-type packing, one out of every eight formula units is missing in $\beta$-TCP and therefore vacancies occur at both cation and anion sites. In $\beta$-TCP the columns are split into two types, both containing cations and anions. Type I retains columns similar to the $\mathrm{Ba}_{3}\left(\mathrm{PO}_{4}\right)_{2}$ structure. The other, type II, has vacancies at both anion and cation sites. Each type II column is surrounded by six type I columns; each type I column is surrounded by four type II and two type I columns. A major difference in the structures of $\alpha$ - and $\beta$-TCP is that there are no cation-cation columns in the $\beta$ form. 


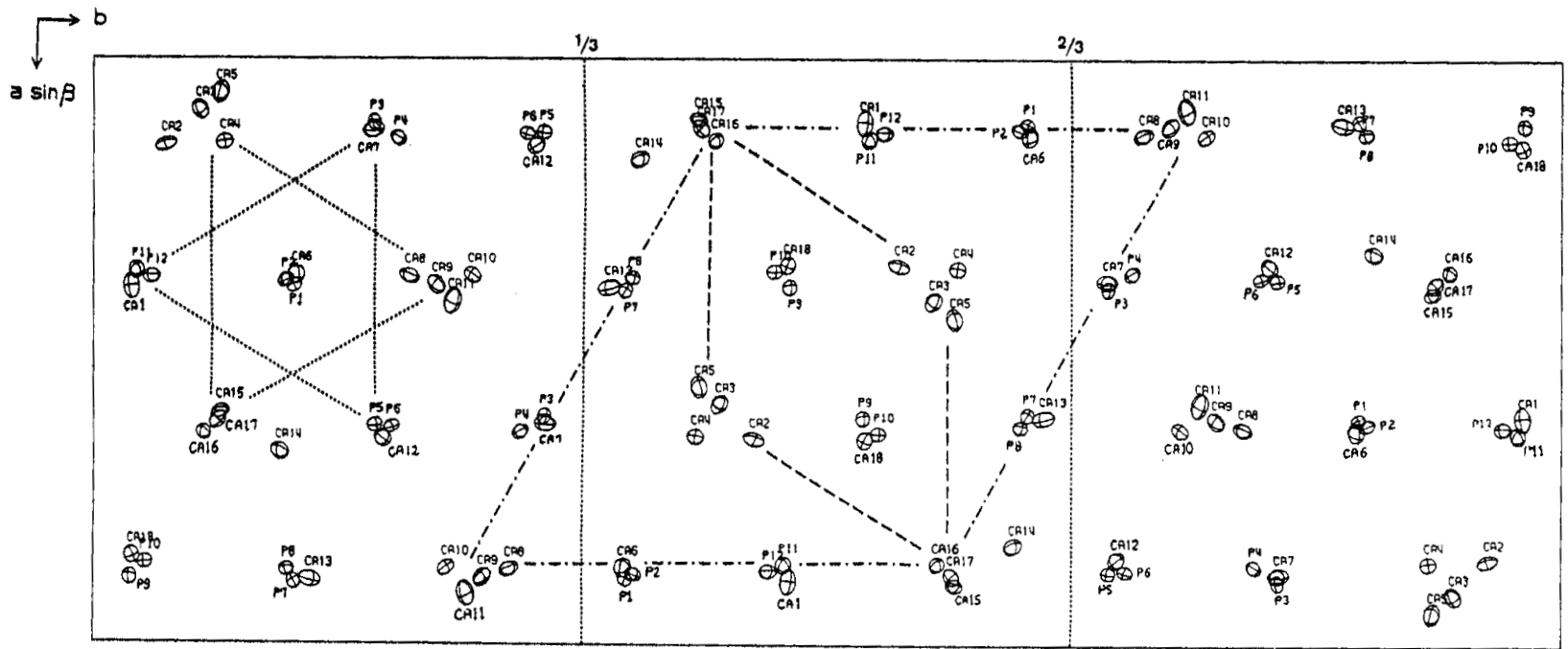

Fig. 5. A projection of the structure of $\alpha-\mathrm{Ca}_{3}\left(\mathrm{PO}_{4}\right)_{2}$ on the (001) plane to show the columnar arrangement. Oxygen atoms of the $\mathrm{PO}_{4}{ }^{3-}$ groups have been omitted for clarity. The dashed lines in the center outline a cell corresponding to that of glaserite, while the dashed-dotted lines correspond to that of OHAp.

\subsubsection{Mg Substitutions in TCP}

Incorporation of $\mathrm{Mg}^{2+}$ into $\alpha$ - and $\beta$-TCP produces some interesting structural features. A small amount of $\mathrm{Mg}^{2+}$ stabilizes the $\beta$-TCP structure. Since the $\mathrm{x}$-ray powder patterns of whitlockite and $\beta$-TCP or Mg-containing $\beta$-TCP are not easily distinguished, the names have been used interchangeably and synonymously. However, the structural studies have shown that the mineral whitlockite has a formula that approximates $\mathrm{Ca}_{18}(\mathrm{Mg}, \mathrm{Fe})_{2} \mathrm{H}_{2}\left(\mathrm{PO}_{4}\right)_{14}$ and that the structure is very closely related to $\beta$-TCP [28]. The incorporation of $\mathrm{Mg}^{2+}$ into $\beta$-TCP and $\mathrm{Mg}^{2+}$ and $\mathrm{HPO}_{4}{ }^{2-}$ substitutions in whitlockite take place in type II columns with vacant sites. Increased substitution of $\mathrm{Mg}^{2+}$ also stabilizes the $\alpha$-TCP structure, as indicated by the structural study of $\mathrm{Ca}_{7} \mathrm{Mg}_{9}(\mathrm{CaMg})_{2}\left(\mathrm{PO}_{4}\right)_{12}$ [35] which is closely related to $\alpha$-TCP. The incorporation of $\mathrm{Mg}^{2+}$ into $\alpha$-TCP shows that substitution occurs at the cation sites in the cationanion columns.

\subsubsection{Amorphous Calcium Phosphate}

Amorphous calcium phosphate (ACP) based on the generally considered molecular formula, $\mathrm{Ca}_{3}\left(\mathrm{PO}_{4}\right)_{2} \cdot \mathrm{nH}_{2} \mathrm{O}$ [36] may also be included as a tricalcium phosphate. Although there is no conclusive evidence for ACP as an integral mineral component in hard tissues, it plays a special role probably as a transient phase in biomineralization. In solution, ACP is readily converted to stable crystalline phases such as OCP or apatitic products. Based on radial distribution analysis of the x-ray diffraction profile it has been proposed that the basic unit of ACP consists of a $9.5 \AA$ diameter, roughly spherical, cluster of ions $\mathrm{Ca}_{9}\left(\mathrm{PO}_{4}\right)_{6}$ corresponding to the central apatite region [37]. The water molecules occupy the inter-cluster spaces between the aggregates of these clusters. However, Extended X-Ray Absorption Fine Structure (EXAFS) studies indicate that local order is only around $3.0 \AA$ [38]. Infrared analysis also shows a similar lack of crystalline order [39]. This apparent lack of crystallinity is one of the more striking features of ACP. Yet the constancy in the composition of ACP over a wide range of solution conditions suggests a well-defined structural unit [40].

\section{5 $\mathrm{Ca}^{-\mathrm{PO}_{4}}$ Sheets Containing Compounds}

Dicalcium phosphate dihydrate (DCPD), $\mathrm{CaHPO}_{4} \cdot 2 \mathrm{H}_{2} \mathrm{O}$, occurs as the mineral brushite and crystallizes in the monoclinic space group $I a$ with unit cell parameters $a=5.812(2) \AA, \quad b=15.180(3) \AA, \quad c=$ 6.239(2) $\AA$ and $\beta=116.42(3)^{\circ}, Z=4$ [41]. The opposite edges of $\mathrm{HPO}_{4}{ }^{2-}$ ions are linked to $\mathrm{Ca}^{2+}$ ions to form linear chains that are stacked in a zig-zag fashion to form corrugated sheets parallel to the (010) face (Fig. 6). The water molecules are bonded to the $\mathrm{Ca}^{2+}$ ion and are located between these sheets. The packing of the $\mathrm{Ca}-\mathrm{HPO}_{4}$ chains or the corrugated sheets results in several possible pseudohexagonal arrangements of the $\mathrm{Ca}^{2+}$ and/or $\mathrm{PO}_{4}{ }^{3-}$ columns, reminiscent of the glaserite structure. The $\mathrm{Ca}-\mathrm{HPO}_{4}$ chains or the corrugated sheets are stacked almost exactly on top of one another along the b-axis, but with a translation along the chain such that $\mathrm{HPO}_{4}{ }^{2-}$ groups are above and below a $\mathrm{Ca}^{2+}$ ion in 


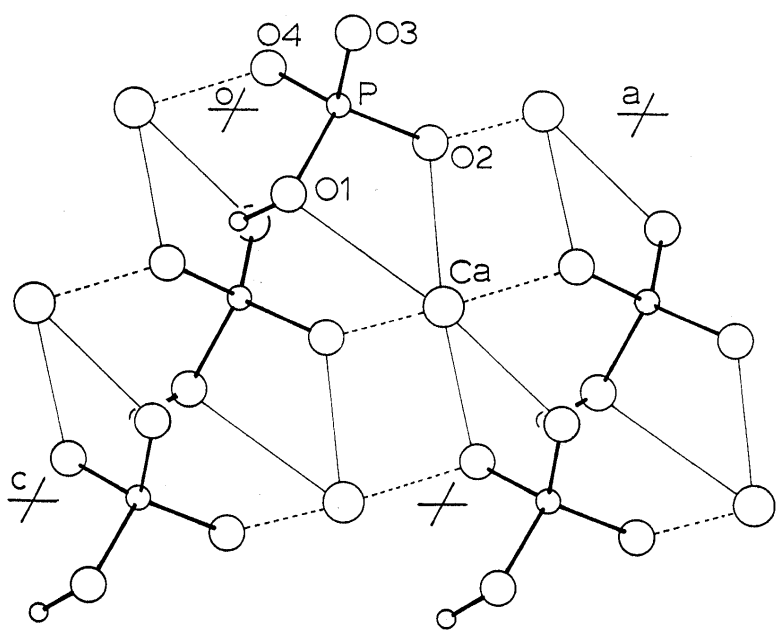

Fig. 6. Crystal structure of DCPD as viewed down the $b$-axis. The $\mathrm{Ca}^{2+}$ and $\mathrm{HPO}_{4}{ }^{2-}$ ions are linked together to form linear chains along [101]. The linkages between chains are indicated by dashed lines. The $\mathrm{Ca}^{2+}-\mathrm{HPO}_{4}{ }^{2-}$ chains are stacked in a zig-zag fashion, forming corrugated sheets parallel to (010). There are two sheets per unit cell, but only one is shown. The two water molecules occupy the interstitial space between the corrugated sheets, but are omitted from this figure.

one sheet, and similarly $\mathrm{Ca}^{2+}$ ions above and below an $\mathrm{HPO}_{4}{ }^{2-}$ group in that sheet. Although there is no direct bonding between $\mathrm{Ca}^{2+}$ and $\mathrm{HPO}_{4}{ }^{2-}$ ions between sheets, the pseudohexagonal arrangement of $\mathrm{Ca}^{2+}$ and $\mathrm{HPO}_{4}{ }^{2-}$ ions in columns (parallel to the $b$-axis) makes DCPD a potential candidate to be included in glaserite-type structures.

Dicalcium phosphate anhydrous (DCPA), $\mathrm{CaHPO}_{4}$, crystallizes in the triclinic space group, $P \overline{1}$, with $a=6.910(1) \quad \AA, \quad b=6.627(2) \quad \AA, \quad c=6.998(2) \AA$, $\alpha=96.34(2)^{\circ}, \beta=103.82(2)^{\circ}$ and $\gamma=88.33(2)^{\circ}, Z=4$ [42]. The structures of DCPD and DCPA are closely related with similar $\mathrm{Ca}-\mathrm{PO}_{4}$ chains arranged in corrugated sheets.

Monocalcium phosphate occurs as the monohydrate (MCPM) and the anhydrous salt (MCPA). Both structures show the presence of $\mathrm{Ca}-\left(\mathrm{H}_{2} \mathrm{PO}_{4}\right)$ chains forming corrugated sheets $[43,44]$ as in $\mathrm{DCPD}$, but with severe distortions due to the presence of $\mathrm{H}_{2} \mathrm{PO}_{4}{ }^{-}$ions between these sheets.

\section{Summary}

The traditional listing of glaserite-type structure covered only the tricalcium phosphates. However, a closer examination of the structures would reveal that all calcium orthophosphates, listed here, can be included as distorted glaserite type structures, but with varying degrees of distortion. The relationship of the apatite structure to that of glaserite can be seen if the triangular $\mathrm{Ca}^{2+}$ and $\mathrm{PO}_{4}{ }^{3-}$ positions are considered to be in very distorted cation-anion columns (II) in a hexagonal arrangement (Figs. 1,5). The centers of two of the hexagonal type II rods are occupied by the column $\mathrm{Ca}^{2+}$ ions, while a third set of hexagonal centers is occupied by the $\mathrm{OH}^{-}$ ion columns instead of cation columns, thus leading to the unusual stoichiometry. Rewriting the formula as $\left(\mathrm{Ca}_{5} \square\right)\left(\mathrm{PO}_{4}\right)_{3}+\mathrm{OH}$ ( $\square$ = vacancy) achieves the desired 2:1 ratio of ions in glaserite and the vacancies filled by the $\mathrm{OH}^{-}$ions. OCP and TTCP are structurally related to apatite. The phosphates containing $\mathrm{Ca}-\mathrm{PO}_{4}$ sheets also reveal some similarity to those of glaserite. Thus, it is possible that all calcium orthophosphates can be listed under glaserite type structures. Glaserite-type structure has been described [31] as one of the most versatile arrangements in mineralogical chemistry, particularly those of phosphates, silicates and sulphates which holds true for biominerals as well.

\section{Acknowledgements}

The work was supported, in part, by USPHS Research Grant DE05030 to the American Dental Association Health Foundation from the National Institutes of Health - National Institute of Dental and Craniofacial Research and is part of the dental research program conducted by the National Institute of Standards and Technology in cooperation with the American Dental Association Health Foundation.

\section{References}

[1] B. Dickens and W. E. Brown, The crystal structure of $\mathrm{CaKAsO}_{4} \cdot 8 \mathrm{H}_{2} \mathrm{O}$. Acta Crystallogr. B28, 3056-3065 (1972).

[2] M. I. Kay, R. A. Young, and A. S. Posner, Crystal structure of hydroxyapatite, Nature 204, 1050-1052 (1964).

[3] J. C. Elliot, P. E. Mackie, and R. A. Young, Monoclinic hydroxyapatite, Science 180, 1055-1057 (1973).

[4] K. Sudarsanan, P. E. Mackie, and R. A. Young, Comparison of synthetic and mineral fluorapatite, $\mathrm{Ca}_{5}\left(\mathrm{PO}_{4}\right)_{3} \mathrm{~F}$, in crystallographic detail, Mat. Res. Bull. 7, 1331-1338 (1972).

[5] J. M. Hughes, M. Cameron, and K. D. Crowley, Structural variations in natural $\mathrm{F}, \mathrm{OH}$, and $\mathrm{Cl}$ apatites, Amer. Mineral. 74, 870-876 (1989).

[6] P. E. Mackie, J. C. Elliot, and R. A. Young, Monoclinic structure of synthetic $\mathrm{Ca}_{5}\left(\mathrm{PO}_{4}\right)_{3} \mathrm{Cl}$, chlorapatite, Acta Crystallogr. B28, 1840-1848 (1972).

[7] K. Sudarsanan and R. A. Young, Structural interactions of F, Cl and $\mathrm{OH}$ in apatites, Acta Crystallogr. B34, 1401-1407 (1978).

[8] J. M. Hughes, M. Cameron, and K. D. Crowley, Crystal structures of natural ternary apatites: Solid solution in the $\mathrm{Ca}_{5}\left(\mathrm{PO}_{4}\right)_{3} \mathrm{X}(\mathrm{X}=\mathrm{F}, \mathrm{OH}, \mathrm{Cl})$ system, Amer. Mineral. 75, 295304 (1990).

[9] J. C. Elliot, D. W.Holcomb, and R. A. Young, Infrared determination of the degree of substitution of hydroxyl by carbonate ions in human dental enamel, Calcif. Tissue Int. 37, 372-375 (1985). 
[10] M. Mathew, W. E. Brown, M. Austin, and T. Negas, Lead alkali apatites without hexad anion: The crystal structure of $\mathrm{Pb}_{8} \mathrm{~K}_{2}\left(\mathrm{PO}_{4}\right)_{6}$, J. Solid State Chem. 35, 69-76 (1980).

[11] L. W. Schroeder and M. Mathew, Cation ordering in $\mathrm{Ca}_{2} \mathrm{La}_{8}\left(\mathrm{SiO}_{4}\right)_{6} \mathrm{O}_{2}$, J. Solid State Chem. 26, 383-387 (1978).

[12] M. Mathew, I. Mayer, B. Dickens, and L. W. Schroeder, Substitution in barium-fluoride apatite: The crystal structures of $\mathrm{Ba}_{10}\left(\mathrm{PO}_{4}\right)_{6} \mathrm{~F}_{2}, \mathrm{Ba}_{6} \mathrm{La}_{2} \mathrm{Na}_{2}\left(\mathrm{PO}_{4}\right)_{6} \mathrm{~F}_{2}$, and $\mathrm{Ba}_{4} \mathrm{Nd}_{3} \mathrm{Na}_{3}\left(\mathrm{PO}_{4}\right)_{6} \mathrm{~F}_{2}, \mathrm{~J}$. Solid State Chem. 28, 79-95 (1979).

[13] W. E. Brown, Octacalcium phosphate and hydroxyapatite: Crystal structure of octacalcium phosphate, Nature 196, 1048-1050 (1962).

[14] M. Mathew, W. E. Brown, L. W. Schroeder, and B. Dickens, Crystal Structure of octacalcium bis(hydrogenphosphate) tetrakis(phosphate) pentahydrate, $\mathrm{Ca}_{8}\left(\mathrm{HPO}_{4}\right)_{2}\left(\mathrm{PO}_{4}\right)_{4} \cdot 5 \mathrm{H}_{2} \mathrm{O}$, J. Crystallogr. Spectrosc. Res. 18, 235-250 (1988).

[15] J. P. Yesinowski and H. Eckert, Hydrogen environments in calcium phosphates. ${ }^{1} \mathrm{H}$ MAS NMR at high spinning speeds, J. Amer. Chem. Soc. 109, 6274-6282 (1987).

[16] B. O. Fowler, M. Markovic, and W. E. Brown, Octacalcium phosphate. 3. Infrared and Raman vibrational spectra, Chem. Mater. 5, 1417-1423 (1993).

[17] W. E. Brown, J. R. Lehr, J. P. Smith, and A. W. Frazier, Crystallographic and chemical relations between octacalcium phosphate and hydroxyapatite, Nature 196, 1050-1055 (1962).

[18] B. Dickens and L. W. Schroeder, Investigation of epitaxy relationships between $\mathrm{Ca}_{5}\left(\mathrm{PO}_{4}\right)_{3} \mathrm{OH}$ and other calcium orthophosphates, J. Res. Natl. Bur. Stand. (U.S.) 85, 347-362 (1980).

[19] W. E. Brown, L. W. Schroeder, and J. S. Ferris, Interlayering of crystalline octacalcium phosphate and hydroxyapatite, J. Phys. Chem. 83, 1385-1388 (1979).

[20] M. Iijima, H. Tohda, and Y. Moriwaki, Growth and structure of lamellar mixed crystals of octacalcium phosphate and apatite in a model system of enamel formation, J. Crystal Growth 116, 319-326 (1992).

[21] W. E. Brown, M. Mathew, and M. S. Tung, Crystal chemistry of octacalcium phosphate. Prog. Crystal Growth Charact. 4, 59-87 (1981).

[22] W. E. Brown, M. Mathew, and L. C. Chow, Roles of octacalcium phosphate in surface chemistry of apatites, Adsorption on and surface chemistry of hydroxyapatite, D. N. Misra, ed., Plenum (1984).

[23] B. Dickens, W. E. Brown, G. J. Kruger, and J. M. Stewart, $\mathrm{Ca}_{4}\left(\mathrm{PO}_{4}\right)_{2} \mathrm{O}$, tetracalcium diphosphate monoxide. Crystal structure and relationships to $\mathrm{Ca}_{5}\left(\mathrm{PO}_{4}\right)_{3} \mathrm{OH}$ and $\mathrm{K}_{3} \mathrm{Na}\left(\mathrm{SO}_{4}\right)_{2}$. Acta Crystallogr. B29, 2046-2056 (1973).

[24] W. E. Brown and L. C. Chow, A new calcium phosphate, water setting cement, in Cements Research Progress, 1986, P. W. Brown, ed., American Ceramic Society, Ohio (1987) pp. 352379.

[25] J. H. Welch and W. Gutt, High temperature studies of the system calcium oxide-phosphorus pentoxide, J. Chem. Soc. 4442-4444 (1961).

[26] R. W. Nurse, J. H. Welch, and W. Gutt, High temperature equilibria in the system dicalcium silicate-tricalcium phosphate, J. Chem. Soc. 1077-1083 (1959).

[27] P. Roux, D. Louer, and G. Bonel, Chimie minerale-sur une nouvelle forme cristalline de phosphate tricalcique, Compt. Rend. Acad. Sc. Paris 286, 549-551 (1978).

[28] C. Calvo and R. Gopal, The crystal structure of whitlockite from the Palermo Quarry, Amer. Mineral. 60, 120-133 (1975).

[29] R. Wallaeys and G. Montel, Structure et proprietes du phosphate tricalcique hydrate, Bull. Soc. Chim. France, 496-498 (1959).

[30] B. Gossner, Uber die kristallstruktur von glaserit und kaliumsulfat, Neuse Jahrb. Mineral. Mh. 57A, 89-116 (1928).
[31] P. B. Moore, Complex crystal structures related to glaserite, $\mathrm{K}_{3} \mathrm{Na}\left(\mathrm{SO}_{4}\right)_{2}$ : evidence for very dense packings among oxysalts, Bull. Mineral. 104, 536-547 (1981).

[32] S. Takagi, M. Mathew, and W. E. Brown, A glaserite-type structure: Calcium tripotassium hydrogenbis(phosphate), $\mathrm{CaK}_{3} \mathrm{H}\left(\mathrm{PO}_{4}\right)_{2}$. Acta Crystallogr. C39, 166-169 (1983).

[33] M. Mathew, L. W. Schroeder, B. Dickens, and W. E. Brown, The crystal structure of $\alpha-\mathrm{Ca}_{3}\left(\mathrm{PO}_{4}\right)_{2}$, Acta Crystallogr. B33, 1325-1333 (1977).

[34] B. Dickens, L. W. Schroeder, and W. E. Brown, Crystallographic studies of the role of $\mathrm{Mg}$ as a stabilizing impurity in $\beta-\mathrm{Ca}_{3}\left(\mathrm{PO}_{4}\right)_{2}$. I. The crystal structure of pure $\beta-\mathrm{Ca}_{3}\left(\mathrm{PO}_{4}\right)_{2}, \mathrm{~J}$. Solid State Chem. 10, 232-248 (1974).

[35] B. Dickens and W. E. Brown, The crystal structure of $\mathrm{Ca}_{7} \mathrm{Mg}_{9}(\mathrm{CaMg})_{2}\left(\mathrm{PO}_{4}\right)_{12}$, Tschermaks Miner. Petrogr. Mitt. 16, 79-104 (1971).

[36] J. D. Termine and E. D. Eanes, Comparative chemistry of amorphous and apatitic calcium phosphate preparations, Calcif. Tiss. Res. 10, 171-197 (1972).

[37] F. Betts and A. S. Posner, An x-ray radial distribution study of amorphous calcium phosphate, Mater. Res. Bull. 9, 353-360 (1974).

[38] E. D. Eanes, L. Powers, and J. L. Costa, Extended X-ray absorption fine structure (EXAFS) studies on calcium in crystalline and amorphous solids of biological interest, Cell Calcium 2, 251-262 (1981).

[39] J. D. Termine and D. R. Lundy, Vibrational spectra of some phosphate salts amorphous to $\mathrm{x}$-ray diffraction, Calcif. Tiss. Res. 15, 55-70 (1974).

[40] E. D. Eanes, Amorphous calcium phosphate: Thermodynamic and Kinetic considerations, in Calcium Phosphates in Biological and Industrial Systems, Zahid Amjad, ed., Kluwer Academic Publishers (1998).

[41] N. A. Curry and D. W. Jones, Crystal structure of brushite, calcium hydrogen orthophosphate dihydrate, A neutron-diffraction investigation, J. Chem. Soc. (A) 3725-3929 (1971).

[42] B. Dickens, J. S. Bowen, and W. E. Brown, A refinement of the crystal structure of $\mathrm{CaHPO}_{4}$ (synthetic monetite), Acta Crystallogr. B28, 797-806 (1972).

[43] B. Dickens and J. S. Bowen, Refinement of the crystal structure of $\mathrm{Ca}\left(\mathrm{H}_{2} \mathrm{PO}_{4}\right)_{2} \cdot \mathrm{H}_{2} \mathrm{O}$, Acta Crystallogr. B27, 2247-2255 (1971).

[44] B. Dickens, E. Prince, L. W. Schroeder, and W. E. Brown, $\mathrm{Ca}\left(\mathrm{H}_{2} \mathrm{PO}_{4}\right)_{2}$, a crystal structure containing unusual hydrogen bonding, Acta Crystallogr. B29, 2057-2070 (1973).

\footnotetext{
About the authors: Mathai Mathew is a crystallographer in the Dental Crystallography Division of the Paffenbarger Research Center, American Dental Association Health Foundation at NIST. Shozo Takagi is a crystallographer, currently in the Cariology Division of the Paffenbarger Research Center, American Dental Association Health Foundation at NIST. The National Institute of Standards and Technology is an agency of the Technology Administration, U.S. Department of Commerce.
} 